\title{
TOWARDS UNDERSTANDING THE COLONIAL HERITAGE IN ALGERIA: THE CASE OF THE SHERIDAN VILLA
}

\author{
${ }^{1}$ Hiba BARBARA, ${ }^{2}$ Tamás MOLNÁR ${ }^{*}$ \\ ${ }^{1}$ Breuer Marcel Doctoral School, Faculty of Engineering and Information Technology \\ University of Pécs, Boszorkány u. 2, H-7624 Pécs, Hungary, \\ e-mail: barbara.hiba6@gmail.com \\ ${ }^{2}$ Department of Visual Studies, Faculty of Engineering and Information Technology \\ University of Pécs, Boszorkány u. 2, H-7624 Pécs, Hungary, e-mail: tmolnar@mik.pte.hu
}

Received 2 January 2018; accepted 9 November 2018

\begin{abstract}
The Colonial Heritage is the subject of misconceived interpretations when exploring the historical legacy of French Algeria. The present research interrogates the complexity of the French strategies and the emergence of various architectural styles within the colonial context. The rehabilitation of the Sheridan Villa into an art residency emphasizes the aspirations of the study, from the architectural survey of the monument; to the monograph of its historical evolution, the results indicate severe cases of humid and physical pathologies menacing the stability of the construction. A significant number of similar monuments are dilapidated and hence call for coherent interventions; to upgrade their state of conservation.
\end{abstract}

Keywords: Colonial heritage, French Algeria, Patrimonial identity, Colonial styles, Arabisance, Sheridan villa, Rehabilitation

\section{Introduction}

The concept of heritage in its fundamental definition, stimulates a certain sense of belonging, recalling a shared memory that relates nations to their past. However, when this memory displays an unfortunate sequence of events, the reception of the heritage falls into the traps of controversial ideologies [1]. Furthermore, when the historical approach of patrimony goes beyond the colonial reality, it becomes obscured by questions of pride and identity. As a result; the restricted lecture of the past inhibits the objectivity of the investigations on the colonial heritage.

\footnotetext{
${ }^{*}$ Corresponding Author
} 
Algeria is a North African country, identified by a vast diversity of historical influences; reflecting a unique interaction among the past civilizations. Stating the age of the Numdians; the presence of the Phoenicians and the Carthaginians; the antiquity of the Romans and Byzantines; the domination of Islamic dynasties, the Turkish invasion, and lastly the era of French colonization [2], where this latter indicates a stage of conversion for modern Algeria.

The 132 years of the French existence in Algeria, demonstrate the importance of the urban and architectural productions. Behind the visages of an inherited style pursued by a protective policy, France has marked its achievements in Algeria, by the destruction; the transformation and the creation of many public and private monuments [3], [4], [5]. Moreover, the architecture of the $19^{\text {th }}$ and $20^{\text {th }}$ century of French Algeria introduces the paradoxical understandings in the contemporary practices of conservation and heritage preservation.

To illustrate the purpose of this research, the work has been structured according to two correlative parts. The first is theoretical, which consists of offering an overview of the French heritage in Algeria, in order to understand the architectural and the constructive genesis of these vestiges, therefore to outline the characteristics and the reasons behind their creations. As follows the second part is practical, with the aim of presenting the situation of the Algerian heritage; a work on a case study was conducted: The Sheridan villa in Biskra, Algeria. The main interest is to set the light on the limitations of both the methodological and practical approach towards this period. After a profound historical documentation on the building, assessing its current state, and diagnosing its pathologies, the final proposition was the intervention project: the rehabilitation of the Sheridan villa into an art residency, in the aim of revaluing the monument to a better state and prescribing the right remedies to its problems.

\section{The colonial legacy: Strategies and architectural productions}

The history of the French productions in North Africa emerged with a European fascination for the oriental world. The missionary discoveries of the architects, artists, and writers, in the Middle East and the Maghreb [6], produced a constructive background to support a further architectural vision. The learning process during these periods of voyages was translated into paintings, architectural drawings and technical surveys, followed by detailed descriptions and narratives [7]. This historical documentation is stored to the present days in the French archives.

The region of the Maghreb, inclusive of Morocco, Algeria, and Tunisia shares common historical facts when it comes to the French influence in North Africa, where it began with Algiers 1830, during that time Algeria (1830-1962) was entitled a French colony, unlike Tunisia (1881-1956) and Morocco (1912-1956), that were considered two of France's protectorates [3], [8]. Although different in some details, the architectural productions, as a result, are practically similar. For a long period, the French engineering pursued an identical outlining for this trilogy, where the forms and tendencies of an occidental urbanism proposed a different planning on the indigenous tissue of the cities. 


\subsection{Exhibitions of the colonies}

As a reflection of France's power beyond the seas, the universal expositions were generated within the French territories, manifesting the cultural and built heritage of various world departments related to France, including the North African colonies and protectorates. The exhibitions received an extensive number of visitors, provided with the chance to discover an imaginary France on the far side of the borders. Through the realization of representative monuments (Fig. 1) these expositions revisited the original atmosphere of the colonized countries, by recreating the spatial structure of the traditional city: the Medinas, the Moorish houses, the cafés, the local markets, the religious buildings and the overall planification [3].

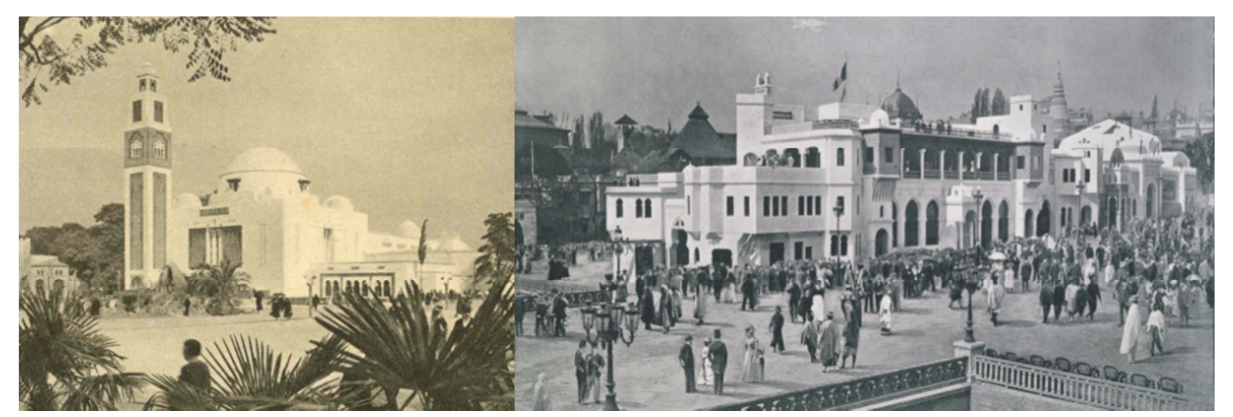

a)

b)

Fig. 1. a) Pavilion of Algeria, colonial exposition, 1930;

b) The Algerian palace of attractions, universal exposition, 1900

One of the famous events is 'the universal exposition' of 1930, organized in Paris. In the case of Algeria, it was an official celebration of the centenary of colonization (18301930), therefore an evident estimation of the architectural achievements. This manifestation welcomed up to 8 million visitors, to experience: a tour around the world in a single day, as it was the official slogan of the occasion. According to Nabila Oulebsir, the adoption of the heritage of the other as one of their own; contradicts the authentic essence of identity [5]. The notion of alterity originated in the exhibition, focuses on the reinterpretation of the autochthon and vernacular architecture, consequently; this reinvented otherness molded in a different context from the original is one of the main perplexities for the colonial heritage.

\subsection{The emergence of the colonial styles in Algeria}

From 1830, starting with Algiers; capital of Algeria, the French heritage was slowly marking its signature in many aspects of the country and was equally readable in the features of the architecture; the details of the constructions, and the aesthetics of the decorative styles. The mirage of an occidental modernity that conceals a traditional locality was the fundamental character of the French interventions in Algeria [3], [4]. Noting three different phases; the military engineer adopted various methodologies facing the original structures of the Algerian cities: 


\section{The neo-classical period (1830-1900): The visage of another France}

The first decade consists of an analytic lecture of the indigenous architecture by decomposing the pre-colonial morphology, besides to the comprehension of the typologies of the traditional Medinas. The motive was to merge these local references with the transported occidental figures of a European tendency. However; from 1830, the application of the European layout on the traditional tissue was contradictorily backed up by many transformation procedures of large parts of the historical center of the Medinas; including the replacement of numerous buildings and the erasure of many others. As follows, the forms of the initial models of the French constructions in Algeria began to take place by reproducing a familiar manner of conceiving; inherited from the classical vocabulary, of the Baroque and Romano-Byzantine [4]. As a consequence emerged the neo-classical style, as it is called: the Vainqueur style, Algeria was a copy of another France (Fig. 2).

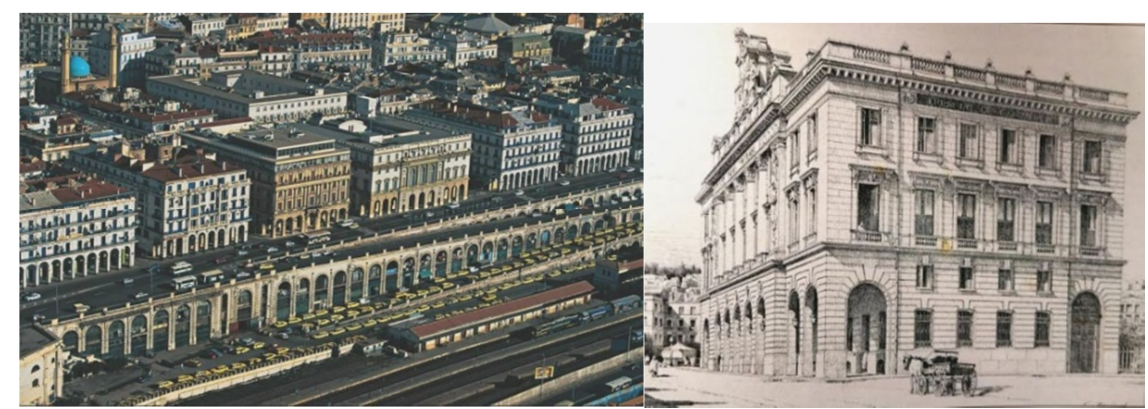

a)

b)

Fig. 2. a) Ziroutyoucef Boulevard, Algiers; b) Consular palace of Algiers

\section{The Neo-Moorish period (1900-1950): A message of reconciliation}

The French approach took a different turn. This period was the transition phase that framed the new colonial image; the protective France, respective to the local culture, which eventually allows, the heritage to find its new balance in French Algeria; reconciling the population to receive an architecture familiar to the figures of their traditions [3].

The Orientalism originated with an influence of the Arab-Moresque culture, on the European art and architecture. After the discovery of the oriental components; and the practice of architectural surveys and archeological excavations, the principals of Orientalism were defined by an occidental perspective on the design procedures [4]. Thus the Arabisance style was born, named also the Neo-Moorish style, or the Jonnart style, following the initial directives of the French general governor of Algiers, 1900 Charles Célestin Jonnart. The Arabisance was a basic reinterpretation of the forms of the local architecture [3].

It is by unlocking the Moorish houses, where the colonization metaphorically reached its apogee, as it was the most private entity of the traditional composition [9]. The passage from an artistic to an architectural orientalism could be translated in 
Women of Algiers, a painting by Eugène Delacroix 1834, along with multiple visualizations of the Arab women, in other artworks and photographs. The emergence of this Moorish renaissance into an official style was achieved by reporting the interior ambiance and the social life. Hence the value of the Moorish houses is validated in the particularity of the interiors, the design of the patios, and the ornamentation of the arcades and galleries. From 1900 to 1925, the Arabisance began to penetrate into the Algerian society, with an enlargement in the field of the architectural references that led to a progressive diversification of the presented models. The conception of public buildings and prestigious constructions (Fig. 3) presented the main interest of the Arabisance [3], [4].

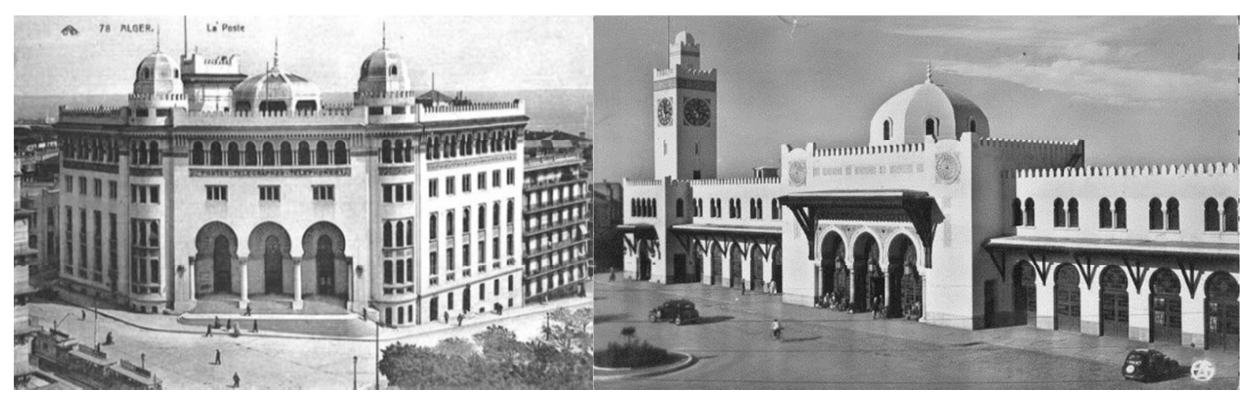

a)

b)

Fig. 3. a) The post of Algiers, Algeria; b) Railway station, Oran, Algeria

The Modernism period (1950): A continuation to the Arabisance

The time of modernity appears to be an alternative to the Arabisance, where both periods have similar objectives, and a respectful attitude towards the local identity. Inspired by vernacular architecture, the modernist movement was characterized with a composite style. From 1920 to 1935, new materials of construction were introduced in Algeria, exporting modern techniques form the metropolitan experience specially the introduction of metallic structures. A group of French architects, mostly born in Algeria, named the Algerianists, were somehow the new faces of this vacancy. Ronald Simounet and many other names, including Marcel Lathuillére and Le Corbusier proposed a new impression on the Moorish architecture, to understand the specific adaptation of this type of constructions with the site and climate, responding perfectly to the needs of modern life [4]. Many projects were realized to caption the modern manifestation of the architects, symbolized by a character of rationalism, and minimalism, delivering a revisited authenticity of the vernacular forms.

The opposition between the pre-colonial and the colonial city is injudicious to the homogeneity of the urban ensemble, the image of the local city, becomes only a decorative system, opposing to a fundamental structure. The respective interpretation though superficial of the vernacular and traditional forms, of the local structure, continues to raise the questions of comprehension to the reception of this heritage [4]. 


\section{The case the Sheridan villa}

The Sheridan villa is constructed in the heart of the old oasis of Mcid in the city Biskra, South-East of Algiers, and north-west of the Algerian Sahara. It is named after the English artist Clare Consuelo Sheridan (Fig. 4), sculptress, novelist and cousin of Sir Winston Churchill [10]. With Arabisance architecture and traditional materials, the villa reflects the memory of the Sheridan interlude in the Algerian desert and stands today as an affirmation of this important passage in the history of French Algeria.

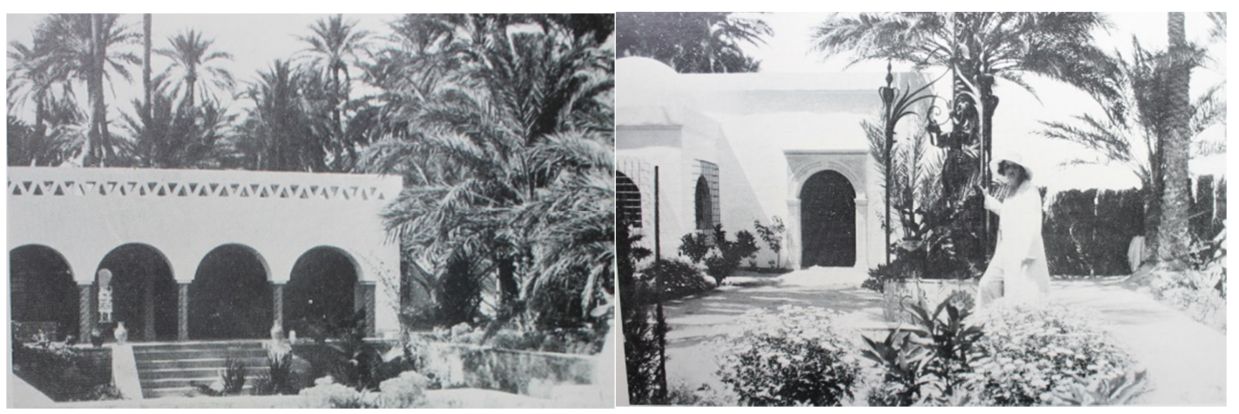

a)

b)

Fig. 4. a) Front of the Sheridan villa; b) Clare Sheridan and the Studio building

Arab interlude, a book written by Clare Sheridan on her experience in Biskra, and collected from the national library of London, was an essential part in the historical documentation, according to the information, the villa was under construction for a period of 2 years, between 1920 and 1922. The conceptual design was imagined by the artist, however the construction work was the responsibility of Ali Slimane, a local mason, who also introduced her to the use of earth materials: mud bricks in the totality of the construction that was available in the site. The villa won the admiration of both the locals and Europeans described as 'Le Petit Palais de Mille et Une Nuit', a small palace of one thousand and one night.

The decorative style of the house was conceived, with rich details, and a variety of artistic patterns, inspired from different parts of the world, visited by the artist, and imprinted in her residence; Neo-Moorish, Persian, and Turkish details, the artist showed big attention to each corner of the house [11], thus this diversity is marked in the particularities of the floor tiles (Fig. 5), the design of the doors, to the detailed shapes of the columns (classical and twisted forms), reflecting the Arabisance style of the period. The Sheridan villa presents, various historical, architectural, esthetic and even social values, that added to the importance of this monument perfectly integrated into the Arab mode of life.

\subsection{Methodology: problems and objectives}

The Villa of Clare Sheridan; the subject of study is one the marking colonial NeoMoresque constructions in the city of Biskra. It stands today, in a very bad conservation state (Fig. 6). Unfortunately, due to actions of time and climate, major parts are severely degraded, while other pathologies are threatening the stability of the construction. 
Currently, the monument is in danger, unrecognizable behind a big garden and difficult to identify, with serious risks of fully collapsing if no emergency measures are taken into consideration.
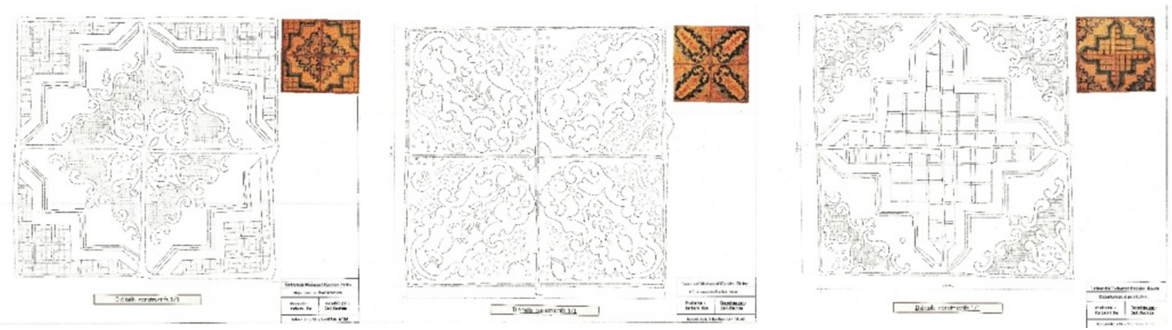

Fig. 5. The technical survey of some floor tiles, based on rescaled photographs
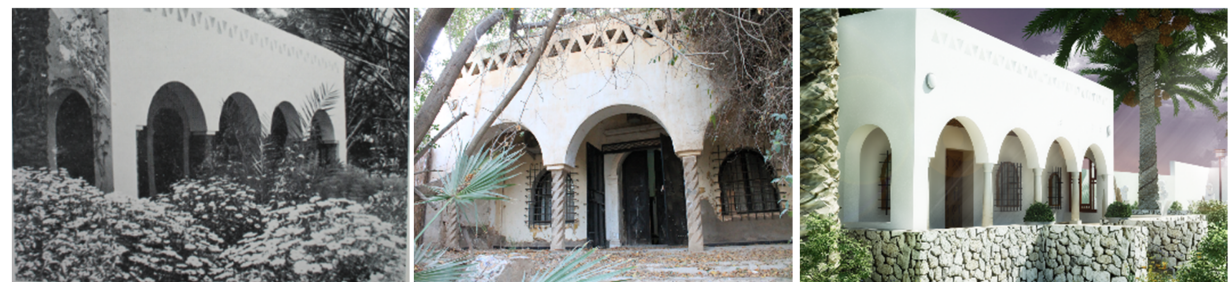

Fig. 6. The Sheridan villa, between the past, the present, and the future

The questions that arise, when dealing with the issues of heritage protection are diverse, how to revalue this forgotten monument, what are the procedures to be taken in order to start the work of preservation, what are the useful functions, which help to conserve this ancient heritage to the future generations [12], [13], [14], [15]. The main objective of the study was to discover the history of the monument, with a big concentration on the diagnosis of the problems and pathologies, to finally treat them with the right remedies, which eventually helps the project of intervention: the rehabilitation of the villa into an art residency. This latter focuses on the interest of associating a topical theme to guide the process, regarding the type of the project, the topic was the study of lighting, in artistic spaces to serve the needs of the art residency.

The architectural assessment and the historical documentation create the fundaments of the work. The research consists of several visits to the project site, taking measurements, pictures, and sketches of the monument, this phase is based on observation and a profound investigation, while the historical documentation, is the essence for the all monographic research, in order to rebuild the history of the construction and the transformations that marked it, by the collection of ancient documents, books, photographs, narratives and all information with direct or indirect relation to the case of study. After analyzing the existing state of the house, the diagnosis and the treatment of the pathologies are necessary to form the base to the intervention project. The last step is the study of different examples related to the new suggested function, to be adapted to the existing spatial and architectural organization of the house. 


\subsection{The Sheridan villa through time}

Generally the construction did not have many modifications in the spatial organization; nevertheless, reckless divisions were performed, due to some issues between the owners of each part of the Sheridan complex. The central part, the residential house; property of $\mathrm{Mr}$. Ouamene Bachir, is the topic of the case study, presented with the same authentic style of decoration and ornamentation. The owners of the house were conscious in planning their habitation, in order to create certain homogeneity between the old pieces and the new additions. To study the historical evolution of the construction; an analytical comparison was performed as shown in the example of (Fig. 7) according to the documentation of the collected photographs and the written or spoken narrations about the monument, to mark the differences between the past and the current state of the villa.

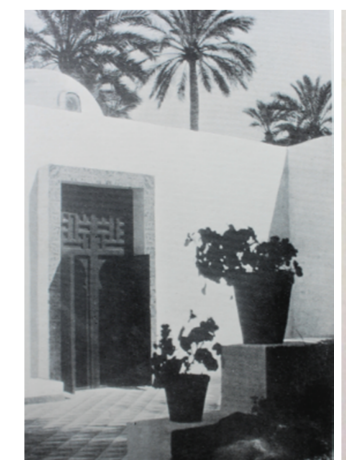

a)

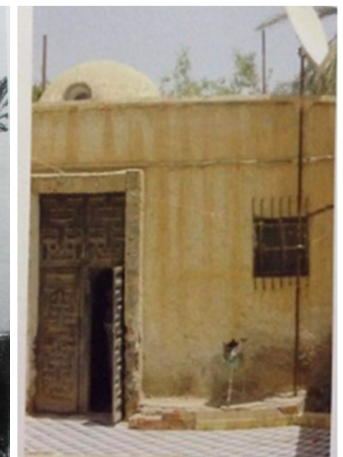

b)

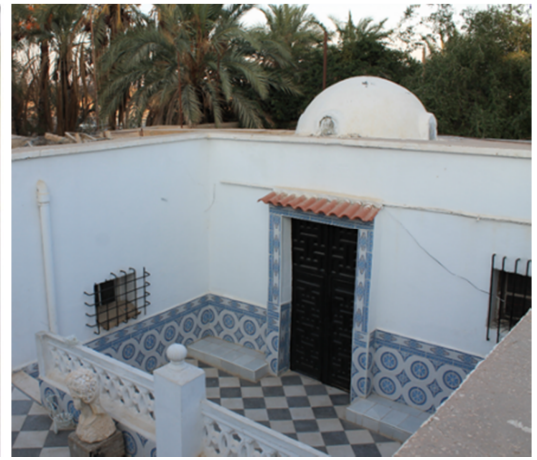

c)

Fig. 7. a) Ancient photograph of the courtyard; b) The courtyard in 2014; c) The courtyard today

\subsection{Architectural survey and state of conservation}

The investigation on the site and the operation of measurement was achieved manually with classical instruments and techniques starting from 1/10/2015. The assessment of the construction lasted for an unpredictable long period of five months, considering the difficulties of measuring the collapsed parts and figuring out their original functions, not to mention the dilapidated situation of the monument, along with other accessibility problems (Fig. 8).

\subsection{Diagnosis and treatment of pathologies}

The monument is in a severe deterioration because of serious problems related to physic and humid pathologies threatening the stability of the construction. The reparation of the problems is needed, thus specific remedies are suggested for the alterations. According to the observations and the investigations on the field, significant parts of the villa, are attacked by different types of cracking at the level of the façades; the Arcade of the veranda and other construction elements. The Humid pathologies are present in a form of swelling curves in the surfaces of the floor tiles, and stains of water 
infiltration in the walls and ceilings. The rapid aging of the building is definitely caused by a series of serious complications, starting from the physical problems of the ground as proved by the diagnosis to be in a progressive movement caused by the bad drainage of water, especially in the North and West parts of the garden. A new system of drainage around the whole house is needed to resolve the problem. To support the pushing forces of the ground and stop the movement, the system of drainage needs to be associated with the placement of a retaining wall supporting the ancient one, using the same type of stones on the external surface to conserve the authenticity of the construction materials. The abandon of massif spaces, including the lack of maintenance of the construction on the side of the garden is particularly one of the main issues presented in this case study (Fig. 9).
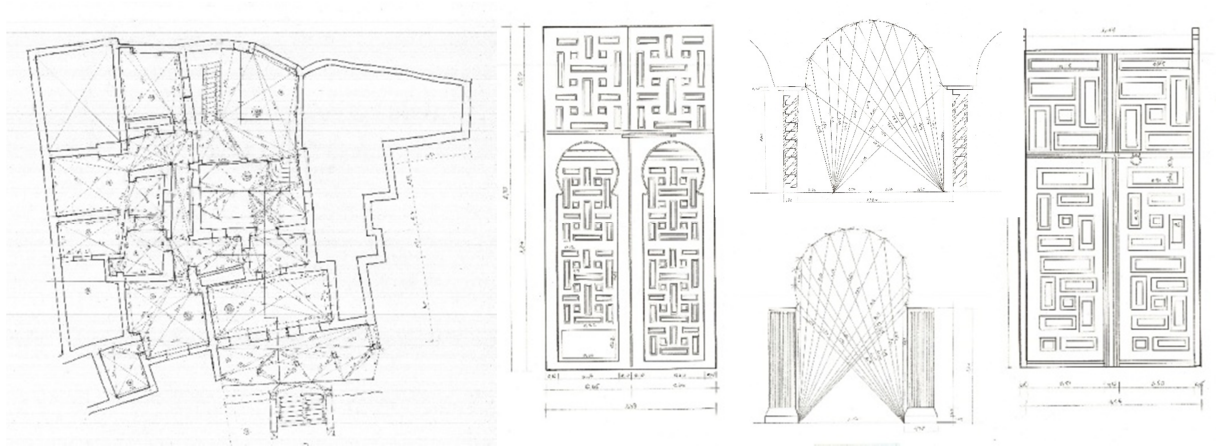

Fig. 8. Samples from the architectural survey of the ground floor and some decorative elements

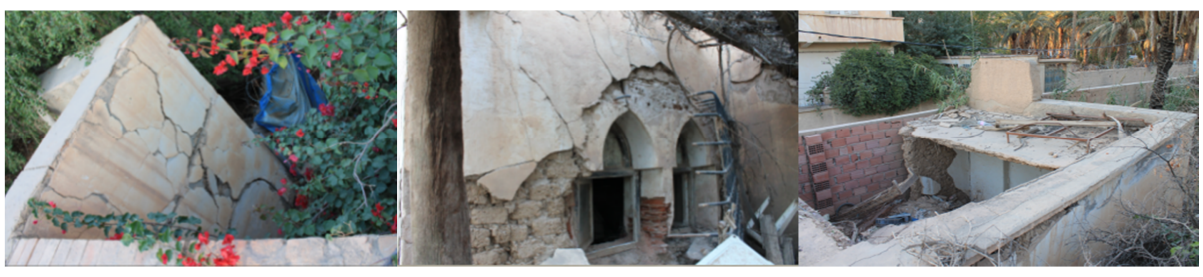

Fig. 9. The observation of different pathologies and alteration

\subsection{The intervention project}

Building on the architectural survey of the Sheridan villa, the intervention project is the final stage, towards the protection of the monument. The rehabilitation into an art residency is supported by the database formed in the historical documentation and the technical survey, as well as analyzing three different projects of a comparable function in France, Senegal and Algeria, for the elaboration of the intervention program. The analysis of the existing organization and design is necessary to adapt the current spaces with the new program. The study of the lighting in the artistic spaces and galleries answers to the needs of the project. Consequently series of actions were suggested, 
starting with the treatment of pathologies, to the rearrangement of the different spaces according to the plan of the artistic residency (Fig. 10).

The garden area was redesigned to benefit from the large space, for outdoor exhibitions and artistic activities such as painting, sculpting, providing to the visitors an overview on the historical value of the villa.
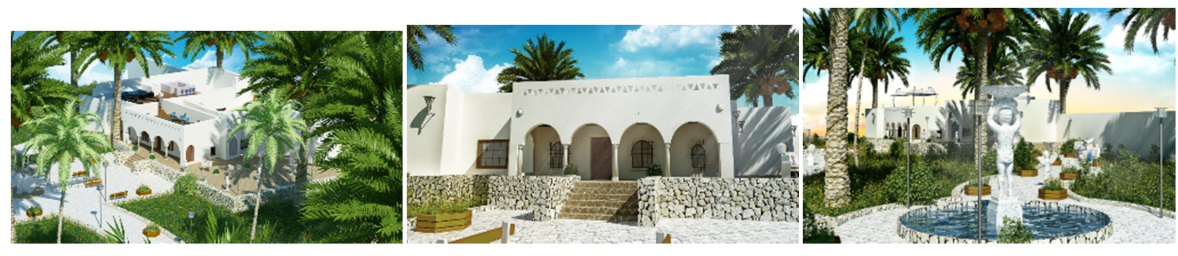

Fig. 10. The rehabilitation of the Sheridan villa into an art residency

According to the historical research, on the villa, an ancient photograph of the East façade was collected, as it looks today the façade does not exist, the suggested action was the restitution of this façade into the original state (Fig. 11).
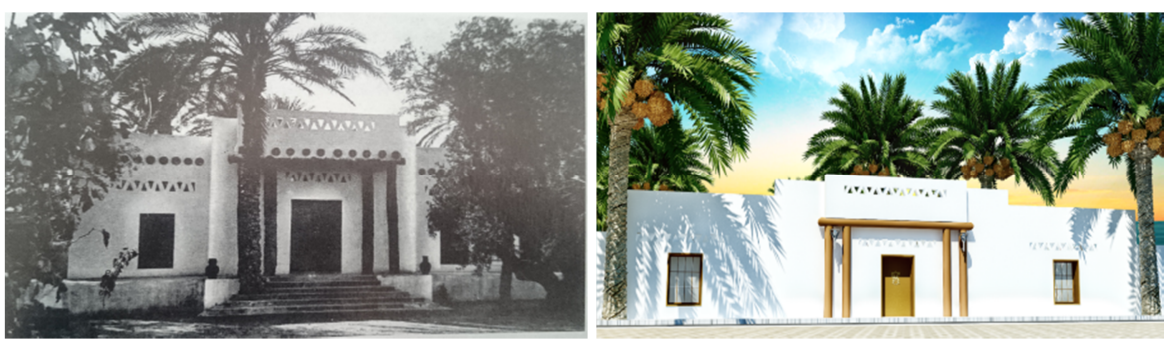

Fig. 11. The restitution of the East façade of the villa, into the original state

The creation of a polyvalent space at the level of the terrace provides a view on the garden and the river of Biskra. A gathering space for artists in the ground floor was designed to reutilize the abundant space. Finally the interior was designed to receive the resident artists, including a gallery for artistic expositions to serve the function of the project.

\section{General conclusion}

The interrogation on critical periods of history creates a vanishing point for all patrimonial interpretations. The oddity of the architectural practices in modern Algeria continues to highlight the contradictions of its national heritage. Thusly; initiatives and interventions on the French built heritage are present; the results remain inconsiderable regarding the bad situation of the monuments today.

The Sheridan villa illustrates the limitations of the research on the French-Algerian legacy. Regardless of the valuable discovery of the building and its history, the elaboration of an intervention on the monument remains a virtual solution, as it was 
never applied in reality. Returning to the Sheridan villa today, it is found in an even worse situation, with an increasing case of serious pathologies and alterations. Whereas the Sheridan villa is not the only case, similar constructions in Algeria are slowly disappearing. The authorities are applying uncertain actions in the field of conservation, while the monuments belonging to the pre-colonial periods are receiving an important interest; the colonial constructions are questioningly neglected.

The Architectural and constructive pragmatics applied in Algeria during the $19^{\text {th }}$ and $20^{\text {th }}$ century and between $1830-1962$, add up to the ambiguity of the subject. The Orientalist concept derived from the occidental discovery missions and resulted in the French exhibitions; simulate a preconception of the local architecture, confusing the authenticity of the pre-colonial constructions. The passage from two specific periods, amidst the neo-classical and the Neo-Moorish period, obstruct the reception of the colonial legacy in the view of the Algerian community.

The scientific investigations on the Arabisance, as ornamental and architectural style, focus initially on the typologies of the monument and the study of its morphological structure, by decomposing the decorative elements, into the most primitive forms. The results of the selected corpus of buildings are generalized on the colonial monuments of the same periods. Although the study serves as an important stylistic recommendation, the understanding of the genesis of these attributes is still questioned, while other studies are addressing the theoretical approach, the interpretation of the results is narrowed to repetitive assumptions.

The determination of the impact of the colonial heritage, on the collective memory of the Algerians, presents one of the possible solutions to clear the obscurities around the subject, whereas including the society and their perception in the process of heritage awareness is vital to reinforce the public conscience to the issues of the heritage in Algeria.

\section{Acknowledgement}

The project of the Sheridan villa was developed in the framework of a Master's Thesis at the University of Mohamed Khider, Faculty of Science and Technology, Department of Architecture and Urbanism, Biskra. Algeria. The authors would like to thank Dali Rachida supervisor and director of the project, the members of the jury who contributed in the discussion of the project Djebnoun Rachid, Nasri Manel. Special gratitude to the owners of the Sheridan villa for providing an access to the building.

\section{Open Access statement}

This is an open-access article distributed under the terms of the Creative Commons Attribution 4.0 International License (https://creativecommons.org/licenses/by/4.0/), which permits unrestricted use, distribution, and reproduction in any medium, provided the original author and source are credited, a link to the CC License is provided, and changes - if any - are indicated. (SID_1) 


\section{References}

[1] Todorov T. Hope and memory: Lessons from the Twentieth Century, Atlentic Books Edition, 2005.

[2] Rachid E. Algeria, Land of fire and light, from prehistory to the war of liberation, (in Franch: L'Algérie terre de feuet de lumière, De la préhistoire à la guerre de libération), el Maarifa Edition, Alger, 2012.

[3] Godin L., Béguin F., Baudez G. Arabisances, Architectual décor and urban layout in North Africa 1830-930, (in French: Arabisances, Décor architectural et trace urbain en Afrique du Nord (1830-1930)), Dunod Bordas, Paris, 1983.

[4] Picard A. Architecture and urbanism in Algeria, From one coast to another 1830-1962 (in French: Architecture et urbanisme en Algérie. D'une rive a l'autre (1830-1962)), In: Figures de l'orientalisme en architecture, C. Bruant, S. Leprun et M. Volait (Eds.), Revue du monde musulman et de la Méditerranée, Vol. 73-74, 1994, pp. 121-136.

[5] Oulebsir N. The uses of patrimony, monument, museum, and colonial politics in Algeria 1830-1930 (in French: Les usages du patrimoine, monument, musée, et politique colonial en Algérie (1830-1930)), Editions de la Maison des sciences de l'homme, Paris, 2004.

[6] Decléty L. French architects, and islamic architecture: First steps towards the history of a style (in French: Les architectes français et l'architecture islamique: les premiers pas vers l'histoire d'un style), Livraisons d'histoire de l'architecture, No. 9, 2005, pp. 73-84.

[7] Oulebsir N. French architects, and islamic architecture: First steps towards the history of a style (in French: La découverte des monuments de l'Algérie, Les missions d'Amable Ravoisié et d'Edmond Duthoit (1840-1880)), in: Figures de l'orientalisme en architecture, C. Bruant, S. Leprun et M. Volait (Eds.), Revue du monde monde musulman et de la Méditerranée, Vol. 73-74, 1994, pp. 57-76.

[8] Jelidi C. Architectural hybridities in Tunisia and Morocco in times of protectorates: Orientalism, regionalism and mediterraneism (in French: Hybridites architecturales en Tunisie et au Maroc au temps des protectorats: Orienttalisme, Régionalisme et Méditerranéisme,) Architectures au Maroc et en Tunisie a l'époquecoloniale, 2009, Tunisie, Bononia University Press, Vol. 2, 2010, pp. 42-62.

[9] Çelik Z. Documenting Algeria: Architecture as a Colonial Agency, AA School of Architecture, https://youtu.be/EUR7mK10fh4, (last visited 11 April 2018).

[10] Pizzaferri P. Biskra, queen of the Ziban and the south of Constantine, (in French: Biskra, reine des Ziban et du Sud constantinois), Vol. 3, Jaques Gandinis Edition, 2011.

[11] Sheridan C. Arab Interlude a continuation of Nuda Veritas, Ivor Nicholson and Watson Edition, London, 1936.

[12] Molnár T. The reconstitution of the archeological museum in Pécs, Pollack Periodica, Vol. 4, No. 3, 2009, pp. 49-56

[13] Messaoudi T., Véron P., Halin G., De LucaL. An ontological model for the reality-based 3D annotation of heritage building conservation state, Journal of Cultural Heritage, Vol. 29, 2018, pp. 100-112.

[14] Fatiguso F., De Fino M., Cantatore E., Caponio V. Resilience of historic built environments: Inherent qualities and potential strategies, Procedia Engineering, Vol. 180, 2017, pp. 1024-1033.

[15] Tamás A. The architecture of recession-solidary architecture, Pollack Periodica, Vol. 10, No. 1, 2015, pp. 163-172. 